\title{
IMPLEMENTASI GAYA KEPEMIMPINAN DAN PENGARUHNYA TERHADAP KINERJA KARYAWAN RUMAH SAKIT SWASTA DI KOTA TOMOHON
}

\author{
Stevianus X. Mentang \\ Jurusan Manajemen, Fakultas Ekonomi, Universitas Negeri Manado \\ Email : stevimentang@unima.ac.id
}

\begin{abstract}
Abstrak:
Tujuan penelitian ini adalah untuk mengetahui bagaimana penerapan gaya kepemimpinan serta seberapa besar pengaruhnya terhadap peningkatan kinerja dari perawat RSU swasta di Kota Tomohon. Jumlah sampel yang digunakan dalam penelitian ini sebanyak 89 responden dengan tingkat error 5\%. Sumber data yang diperoleh menggunakan kuesioner. Analisis data menggunakan;, uji regresi linier berganda,

Secara simultan terdapat pengaruh signifikan gaya kempimpinan direktif, kepemimpianan suportif, kepemimpinan partisipatif, kepemimpianan orientasi pada prestasi terhadap kinerja karyawan terhadap kinerja karyawan. Secara parsial gaya kempimpinan direktif, suportif, partisipatif tidak mempunyai pengaruh terhadap kinerja karyawan sedangkan gaya kepemimpinan orientasi pada prestasi berpengaruh sangat signifikan terhadap kinerja karyawan.
\end{abstract}

Kata kunci : gaya kepemimpinan direktif, suportif, partisipatif, berorientasi pada prestasi, kinerja.

\section{Pendahuluan}

Kepemimpinan merupakan tulang punggung dari pengembangan organisasi karena tanpa pemimpin yang baik akan sulit mencapai tujuan yang ditetapkan. Menjadi seorang pimimpin yang baik tidaklah mudah karena dibutuhkan kemampuan dan kecakapan. Eksistensi sebuah organisasi sangatlah ditentukan oleh pemimpin.

Pada dasarnya setiap orang bisa menjadi pemimpin. Menurut Handayaningrat (1992) kepemimpinan seseorang dalam suatu organsisasi manapun bisa didapatkan berdasarkan keturunan, bisa juga berdasarkan pemilihan atau bisa juga diperoleh berdasarkan penunjukan. Dari manapun seseorang memperoleh status pemimpin, yang paling penting untuk perhatikan bahwa pemimpin yang baik itu adalah orang yang menggambarkan kehendak yang sesungguhnya dari kelompok. Artinya bahwa pemimpin harus bisa mendengarkan suara dari orang yang dipimpin atau dalam hal ini dari para bawahannya.
Pemimpin sebaiknya menumbuhkan sifat optimisme bukannya pesimisme, mau mendengarkan, dan memperjuangkan kesejahteraan organisasi dan yang tidak kalah penting yakni mampu menyelesaikan konflik yang timbul dalam organisasi yang dipimpinnya. Menurut Hasibuan (2012) pemimpin adalah seseorang yang mempergunakan wewenangnya dan kepemimpinannya, mengarahkan bawahan untuk mengerjakan sebagian pekerjaannya dalam mencapai tujuan organisasi.

Siagian (2009) mengungkapkan ada lima tipe kepemimpinan yakni tipe otoriter, tipe paternalistic, tipe laissez faire, tipe demokratik, tipe kharismatik. Dari Tipe-tipe ini dapat dipilih mana yang cocok untuk mempengaruhi hasil kerja bawahan. Pemimpin yang baik harus bisa merangsang bawahan untuk terus berusaha memberikan hasil yang terbaik untuk organisasi tempat bekerja.

Rumah sakit swasta di Kota Tomohon umumnya merupakan badan usaha berbentuk Perseroan Terbatas yang area pelayanannya 
mencakup Kota Tomohon dan Kabupaten Minahasa. Dibutuhkan kepemimpinan yang baik sehingga perseroan dapat terus berdiri dan terus melayani masyarakat. Hal yang tak kalah pentingnya adalah terus menjaga kinerja pelayanan karyawan baik sebagai dokter, perawat ataupun karyawan lainya.

Dalam melaksanakan tugas dan tanggung jawab tidak jarang karyawan dalam hal ini perawat dapat terkena stress akibat tuntutan tugas pelayanan prima ataupun karena sebab lain antra lain oleh sifat pemimpinnya. Tentu saja akibatnya kinerja menjadi terganggu.

Berdasarkan uraian diatas maka rumusan masalah dalam penelitian ini yaitu bagaimana penerapan gaya kepemimpinan serta pengaruhnya terhadap kinerja karyawan di Rumah Sakit swasta di Kota Tomohon?

\section{Tinjauan Pustaka}

\section{A. Kepemimpinan}

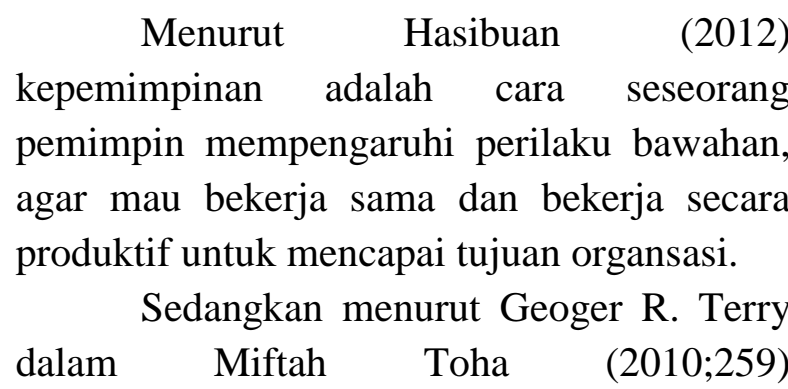
kepemimpinan adalah aktivitas untuk mempengaruhi orang agar diarahkan mancapai tujuan organisasi

Jadi kepemimpinan berarti kegiatan atau aktivitas pemimpin dalam suatu organisasi dalam mempengaruhi bawahan untuk bekerja secara baik untuk mencapai tujuan yang ingin dicapai.

\section{B. Gaya kepemimpinan}

Tipe-tipe gaya kepemimpinan oleh Robert House (Wirjana dan Supardo, 2005) mengungkapkan bahwa gaya kepemimpinan seseorang tergantung situasi yakni:

a. Kepemimpinan Direktif
Pemimpin memberikan nasehat spesifik kepada kelompok dan memantapkan peraturan-peraturan pokok.

b. Kepemimpinan Suportif

Adanya hubungan yang baik antara pemimpin dengan kelompok dan memperlihatkan kepekaan terhadap kebutuhan anggota.

c. Kepemimpinan Partisipatif

Pemimpin mengambil keputusan berdasarkan konsultasi dengan kelompok dan berbagi informasi dengan kelompok.

d. Kepemimpinan Orientasi Prestasi

Pemimpin menghadapkan anggotaanggota pada tujuan yang menantang dan mendorong kinerja yang tinggi sambil menunjukan kepercayaan pada kemapuan kelompok.

Menurut Hasibuan (2012) gaya kepemimpinan dapat dibedakan menjadi tiga yakni;

a. Kepemimpinan otoriter

Pengambilan keputusan dan kebijaksanaan hanya ditetapkan sendiri oleh pimpinan, bawahan tidak diikutsertakan untuk memberikan saran, ide, dan pertimbangan dalam proses pengambilan keputusan.

b. Kepemimpinan partisipatif

Apabila dalam kepemimpinannya dilakukan dengan cara persuasive, menciptakan kerjasama yang serasi, menumbuhkan loyalitas, dan partisipasi para bawahan. Pemimpin memotivasi bawahan agar merasa ikut memiliki perusahaan.

c. Kepemimpinan delegatif

Kepemimpinan delegatif apabila seorang pemimpin mendelegasikan wewenang kepada bawahan dengan agak lengkap. Dengan demikian, bawahan dapat mengambil keputusan dan kebijaksanaan dengan bebas atau leluasa dalam melaksanakan pekerjaannya. 


\section{Kinerja}

Robbins (2006) mendefinisikan kinerja sebagai suatu hasil yang dicapai oleh pegawai dalam pekerjaannya menurut kriteria tertentu yang berlaku untuk sebuah pekerjaan.

Menurut Siagian (2009) kinerja adalah prestasi kerja secara kualitas dan kuantitas yang dicapai seseorang pegawai dalam melaksanakan tugasnya sesuai dengan tanggung jawab yang diberikan kepadanya.

Indikator untuk mengukur kinerja pegawai secara individu ada lima yaitu; (Robbins 2006)

a. Kualitas

Kualitas kerja diukur dari persepsi pegawai terhadap kualitas pekerjaan yang dihasilkan serta kesempurnaan tugas terhadap keterampilan dan kemampuan pegawai.

b. Kuantitas

Merupakan jumlah yang dihasilkan dinyatakan dalam istilah seperti jumlah unit, jumlah siklus aktivitas yang dihasilkan.

c. Ketepatan waktu

Merupakan tingkat aktivtas diselesaikan pada awal waktu yang dinyatakan, dilihat dari sudut koordinasi dengan hasil output serta memaksimalkan waktu yang tersedia untuk aktivitas lain.

d. Efektivitas

Merupakan tingkat penggunaan sumberdaya organisasi (tenaga, uang, teknologi, bahan baku) dimaksimalkan dengan maksud menaikkan hasil dari setiap unit dalam penggunaan sumberdaya.

e. Kemandirian

Merupakan tingkat seorang pegawai yang nantinya akan dapat menjalankan fungsi kerjanya.

\section{Pengaruh gaya kepemimpinan terhadap kinerja karyawan}

Thoha (2010) menjelaskan bahwa dengan menggunakan kepemimpinan maka pemimpin akan mempengaruhi persepesi bawahan dan memotivasinya, dengan cara mengarahkan karyawan pada kejelasan tugas, pencapaian tujuan, kepuasan kerja, dan pelaksanaan kerja yang efektif.

Hal ini dapat diartikan bahwa kepemimpinan mempunyai pengaruh terhadap peningkatan kinerja karyawan.

\section{E. Kerangka konsep}

Kerangka berpikir dari penelitan pengaruh gaya kepemimpinan terhadap kinerja karyawan dapat dirumuskan dengan model sebagai berikut;

Gambar 1

Kerangka Konsep

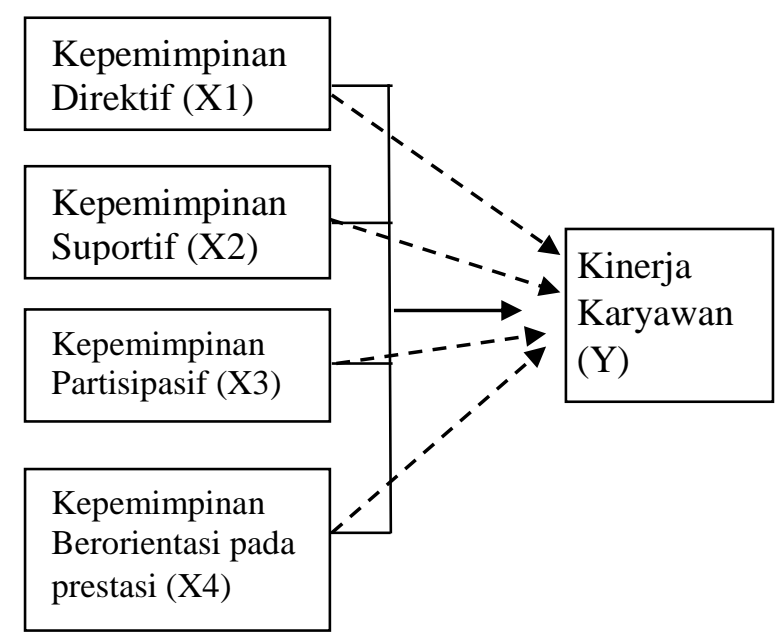

\section{F. Hipotesis}

1. Terdapat pengaruh signifikan variabel $\mathrm{X} 1, \mathrm{X} 2, \mathrm{X} 3, \mathrm{X} 4$ terhadap variabel $\mathrm{Y}$

2. Terdapat pengaruh signifikan dari variabel $\mathrm{X} 1$ terhadap variabel $\mathrm{Y}$

3. Terdapat pengaruh signifikan dari variabel $\mathrm{X} 2$ terhadap variabel Y

4. Terdapat pengaruh signifikan dari variabel X3 terhadap variabel $\mathrm{Y}$

5. Terdapat pengaruh signifikan dari variabel X4 terhadap variabel Y

\section{Metodologi Penelitian}

Populasi dalam penelitian ini adalah perawat Rumah Sakit Swasta di Kota Tomohon. Jumlah sampel yang digunakan 
dalam penelitian ini berdasarkan tabel penentuan sampel yang dikembangkan oleh Isac dan Michael (Sujarweni, 2014) yaitu sebanyak 89 responden dengan tingkat error $5 \%$. Sumber data menggunakan kuesioner menggunakan skala likert.

\section{Definisi Operasional}

Dalam penelitian ini terdapat empat variabel bebas $(\mathrm{X})$ dan satu variabel terikat (Y).

Tabel 1

Definisi operasional

\begin{tabular}{|c|c|c|}
\hline Variabel & Sub variabel & Indikator \\
\hline \multirow[t]{3}{*}{$\begin{array}{l}\text { Gaya } \\
\text { Kepemimpian } \\
\text { an }\end{array}$} & $\begin{array}{l}\text { Kepemimpinan } \\
\text { Direktif (x1) }\end{array}$ & $\begin{array}{l}\text { 1. Pengarahan yang } \\
\text { jelas dari } \\
\text { pemimpin } \\
\text { 2. Pemberian tugas } \\
\text { yang spesifik } \\
\text { 3. Karyawan tau apa } \\
\text { yang harapakan } \\
\text { pemimpin } \\
\text { 4. Pendeskripsian } \\
\text { cara kerja } \\
\text { 5. Pemberian } \\
\text { peraturan yang } \\
\text { jelas }\end{array}$ \\
\hline & $\begin{array}{l}\text { Kepemimpian } \\
\text { suportif (x2) }\end{array}$ & $\begin{array}{l}\text { 1. Menciptakan } \\
\text { suasana kerja } \\
\text { yang kondusif } \\
\text { 2. Memiliki sifat } \\
\text { bersahabat } \\
\text { 3. Memperhatikan } \\
\text { kesejahteraan } \\
\text { karyawan } \\
\text { 4. Memberikan } \\
\text { kesempatan } \\
\text { berpendapat } \\
\text { 5. Menyelesaikan } \\
\text { konflik karyawan }\end{array}$ \\
\hline & $\begin{array}{l}\text { Kepemimpinan } \\
\text { Partisipatif } \\
\text { (x3) }\end{array}$ & $\begin{array}{l}\text { 1. Menyusun tugas } \\
\text { bersama } \\
\text { 2. Mengambil } \\
\text { keputusan } \\
\text { berdasarkan } \\
\text { konsultasi } \\
\text { 3. Berbagi informasi } \\
\text { 4. Berdiskusi } \\
\text { bersama } \\
\text { 5. Menyusun tujuan } \\
\text { kerja bersama }\end{array}$ \\
\hline
\end{tabular}

\begin{tabular}{|l|l|l|}
\hline & $\begin{array}{l}\text { Kepemimpinan } \\
\text { berorientasi } \\
\text { pada prestasi } \\
(\mathrm{x} 4)\end{array}$ & $\begin{array}{l}\text { 1. Mendorong } \\
\text { kinerja tinggi }\end{array}$ \\
& & $\begin{array}{l}\text { 2. Percaya } \\
\text { kemampuan } \\
\text { karywan } \\
\text { 3. Menghadapkan } \\
\text { anggota pada } \\
\text { tujuan } \\
\text { menantang }\end{array}$ \\
& & $\begin{array}{l}\text { 4. Menetapkan } \\
\text { tujuan }\end{array}$ \\
\hline Kinerja (Y) & & $\begin{array}{l}\text { 1. Kualitas kerja } \\
\text { 2. Kuantitas kerja }\end{array}$ \\
& & 3. Ketepatan waku \\
& & 4. Efektivitas kerja \\
& & 5. Kemandirian \\
\hline
\end{tabular}

\section{Analisis Data}

Sebelum pengambilan data dilakukan maka terlebih dahulu dilakukan pengujian validitas dan reliabilitas terhadap daftar pertanyaan yang digunakan. Analisis data menggunakan;, uji regresi linier berganda, bersamaan dengan uji asumsi klasik. Sebelumnya telah dilakukan uji normalitas yang hasilnya data memiliki distribusi normal yang artinya data yang digunakan baik dan layak untuk dianalisis.

Model analisis ini dipilih untuk mengetahui besarnya pengaruh masingmasing variabel bebas terhadap kinerja karyawan, baik secara bersama-sama maupun secara parsial. Pengujian hipotesis dengan regresi digunakan alat analisis sebagai berikut;

a) Pengujian regresi secara simultan / serentak (uji f)

b) Pengujian regresi secara parsial (uji t)

c) Koefisien determinasi $\left(\mathrm{R}^{2}\right)$

\section{Hasil Penelitian dan Pembahasan}

1. Pengaruh simultan Gaya Kepemimpinan Direktif, Kepemimpianan Suportif, Kepemimpinan Partisipatif, Kepemimpianan orientasi pada prestasi terhadap Kinerja Karyawan.

Berdasarkan hasil analisis data menunjukan bahwa nilai $F$ tabel 
menggunakan satu sisi (5\%) sebesar 2,480. Sementara nilai f hitung sebesar 401.678. Jika dibandingkan antara nilai $\mathrm{f}$ hitung dan $\mathrm{f}$ tabel maka hasilnya adalah $\mathrm{f}$ hitung lebih besar dari $\mathrm{f}$ tabel. Maka untuk $\mathrm{f}$ hitung $>$ dari $\mathrm{f}$ tabel $\mathrm{h} 1$ diterima. Jadi secara simultan ada pengaruh antara gaya kempimpinan Direktif, Kepemimpianan Suportif, Kepemimpinan Partisipatif, Kepemimpianan orientasi pada prestasi terhadap Kinerja Karyawan terhadap kinerja karyawan.

\section{Pengaruh Gaya kepemimpinan direktif terhadap Kinerja karyawan secara parsial.}

Berdasarkan hasil analisis data menunjukan bahwa $\mathrm{t}$ hitung sebesar -0,485. Nilai signifikansi sebesar 0,629 yang mana menunjukan bahwa nilai sig $>0,05$. Jadi secara parsial tidak ada pengaruh variabel X1 terhadap Y.

\section{Pengaruh Gaya kepemimpinan suportif terhadap Kinerja karyawan.}

Berdasarkan hasil analisis data menunjukan bahwa t hitung sebesar -1,346. Nilai signifikansi sebesar 0,182 yang mana menunjukan bahwa nilai sig $>0,05$. Jadi secara parsial tidak ada pengaruh variabel X2 terhadap Y.

\section{Pengaruh Gaya kepemimpinan} partisipatif terhadap Kinerja karyawan.

Berdasarkan hasil analisis data menunjukan bahwa bahwa nilai $\mathrm{t}$ hitung sebesar -1,237. Nilai signifikansi sebesar 0,220 yang mana menunjukan bahwa nilai sig $>0,05$. Jadi secara parsial tidak ada pengaruh variabel X3 terhadap Y.

5. Pengaruh Gaya kepemimpinan berorientasi pada prestasi terhadap Kinerja karyawan.

Berdasarkan hasil analisis data menunjukan bahwa t hitung sebesar 10.701. Nilai signifikansi sebesar 0,00 yang mana menunjukan bahwa nilai sig $<0,05$. Jadi secara parsial terdapat pengaruh variabel $\mathrm{X} 4$ terhadap Y.

\section{Analisis Koefisien Determinasi}

Nilai R square adalah sebersar 0,934 . Hal ini berarti keempat variabel bebas mempunyai pengaruh sebesar 93\% pada kinerja karyawan.

\section{Variabel Independet yang paling dominan terhadap variabel dependent}

Variabel bebas yang paling dominan berpengaruh terhadap kinerja karyawan (Y) ditunjukan pada nilai koefisien regresi, dimana menunjukan bahwa yang mempunyai nilai tertinggi adalah variabel $\mathrm{X} 4$.

\section{Kesimpulan}

Berdasarkan hasil penelitan maka dapat disimpulkan bahwa:

1. Keempat variabel $(\mathrm{X} 1, \mathrm{X} 2, \mathrm{X} 3, \mathrm{X} 4)$ secara simultan mempunyai pengaruh terhadap Y. Hal ini berarti bahwa meningkatnya kinerja karyawan dipengaruhi oleh gaya kepemimpinan yang direktif, suportif, partisipatif dan berorientasi pada prestasi.

2. Gaya kepemimpinan direktif tidak mempunyai pengaruh signifikan terhadap Y. Hal ini berarti bahwa kinerja karyawan tidak akan mengalami perubahan dengan diterapkannya kepemimpinan direktif.

3. Gaya kepemimpinan suportif tidak mempunyai pengaruh signifikan terhadap Y. Hal ini berarti secara mandiri kepemimpian ini tidak mempengaruhi kinerja karyawan.

4. Gaya kepemimpian partisipatif tidak mempunyai pengaruh signifkan terhadap Y. Hal ini berarti kepemimpinan jenis ini secara mandiri tidak mempengaruhi kinerja karyawan.

5. Gaya kepemimpian berorientasi prestasi Mempunyai pengaruh signifikan terhadap Y. Hal ini berarti secara mandiri variabel kepemimpinan ini mendorong kinerja karyawan menjadi lebih baik. 
Saran

1. Pemimpin perusahaan sebaiknya menerapkan semua gaya kemimpinan dengan baik sehingga dapat memacu kinerja karywan menjadi lebih baik.

2. Pemimpin perusahaan sebaiknya mempraktekan gaya kepemimpinan yang cocok atau lebih meningkatkan lagi gaya direktif supaya kinerja karyawan mengingkat dan bisa mencapai tujuan yang ingin dicapai.

3. Gaya kepemimpinan suportif sebaiknya lebih ditingkatkan lagi sehingga dapat berpengaruh pada kinerja karyawan menjadi baik.

4. Gaya kepemimpinan partisipatif sebaiknya lebih tingkatkan sehingga memicu kinerja karyawan menjadi lebih baik.

5. Gaya kepemimpinan berorientasi pada prestasi sangat penting untuk terus dipraketekan dan dikembangkan lagi sehingga kinerja karyawan semakin hari semakin baik dan tujuan perusahaan menjadi dapat dicapai.

\section{Daftar Pustaka}

Gibson, M. 2008. Manajemen Sumber Daya Manusia. Cetakan ke dua. Jakarta: Erlangga

Handayaningrat, Soewarno. 2002. Pengantar Studi Ilmu Administrasi dan Manajemen.

Hasibuan. 2012. Manajemen Sumber Daya Manusia. Jakarta: PT. Bumi Aksara.

Thoha, Miftah. 2010. Kepemimpinan dalam manajemen. Cetakan ke 15. Jakarta: Rajawali Press.

Robbins, Stephen. 2006. Manajemen. Edisi kedelapan / jilid 2. Jakarta: PT. Grafindo

Sugiyono. 2010. Metodologi Penelitian Bisnis. Cetakan ke dua belas. Bandung: CV Alfabeta.

Siagian, Sondang P. 2009. Teori Dan Kepemimpinan. Jakarta: Penerbit Rineka Cipta.

Sujarweni. 2014. Metode Penelitian: Lengkap, Praktis, dan Mudah Dipahami. Yogyakarta: Pustaka Baru Press.

Wirjana, dan Supardo. 2005. Kepemimpinan, Dasar-Dasar dan Pengembangannya. Yogyakarta: CV. Andi offset. 